Vasant Chabukswar ${ }^{1}$ and Ganesh Sable ${ }^{2}$

\title{
CHEMICAL OXIDATIVE SYNTHESIS AND CHARACTERISTION OF ORGANICA ACID DOPED SOLUBLE CONDUCTING POLY(O-ANISIDINE)
}

\author{
Department of Chemistry, N owrosjee Wadia College, Pune-411001, India
}

vvchabuk@yahoo.com

Received: December 18, 2008

(c) Chabukswar V., Sable G. 2009

\begin{abstract}
Synthesis of poly(o-anisidine) with and without acrylic acid doping is carried out by chemical oxidative polymerization method. This is a new polymerization method for the direct synthesis of the emeraldine salt of poly $(o-$ anisidine), i.e. it is directly soluble in known organic solvent such as $m$-cresol, $N$-methyl pyrrolidone (NMP), DMSO, DMF, etc. without the need for a conversion of salt phase to base form. The reaction is unique since it eliminates the post processing step which involves neutralization of emeraldine salt to form emeraldine base and again reprotonating the base with a secondary protonic acid.

The acrylic acid doped polymer prepared using tartaric acid is comparatively more soluble in $m$-cresol and NMP than the poly $(o$-anisidine) prepared without acrylic acid. UV-visible spectra for acrylic acid doped poly ( $o$-anisidine) reveals the coil conformation at higher wavelength $\sim 800$ $1000 \mathrm{~nm}$ along with sharp peak $\sim 440 \mathrm{~nm}$, which may be attributed to secondary doping due to extended coil conformation. Whereas in the presence of NMP as a solvent, the extended tail at higher wavelength disappears while a sharp peak $(\sim 630 \mathrm{~nm})$ is observed representing the polymer insulting emeraldine base form. This fact confirms the effect of the solvent on the polymer properties. This is further manifested by the FT-IR spectral studies. Broad and intense band at $\sim 3300-3200 \mathrm{~cm}^{-1}$ and $1100-1200 \mathrm{~cm}^{-1}$ in acrylic acid doped polymer accounts for higher degree of doping. The conductivity of acrylic acid doped poly $(o$-anisidine $)$ is greater than poly $(o-$ anisidine) without acrylic acid. The change in resistance of tartaric acid doped poly (o-anisidine) prepared in acrylic acid media upon its exposure to ammonia vapor suggests the applicability of these polymeric materials for ammonia.
\end{abstract}

Key words: poly( $o$-ansidine), solubility, conductivity, acrylic acid dopant.

\section{Introduction}

Poly $(o$-anisidine $)$ is an important conjugated conducting polymer[1-3]. It is relatively easy to be prepared. The major problem of its successful utilization is poor mechanical properties like lower conductivity and poor solubility in common organic solvents. Recently much progress has been made to improve these poor mechanical properties by using different organic acids as dopant or stabilizer [4-6]. This dopant, like organic acid and acrylic acids, is introduced by simple secondary doping or by blending the polymer with doping species such as acrylic acid. This chemical oxidative polymerization method provides polymers better solubility in common organic solvents such as $m$-cresol, NMP, DMF, etc. These polymers also have better conductivity, which is very important from application point of view, because conductivity of polymer changes on exposing the polymer materials to ammonia vapors or other gases like $\mathrm{H}_{2} \mathrm{~S}$ [6-9].

In the present work we report the chemical oxidative synthesis of electrically conducting and organically soluble acrylic acid doped poly(o-anisidine). This reaction is unique since the polymer obtained has maximum solubility in common organic solvent directly without the need for a post doping process step, which involves conversion of salt phase to base form of the polymer. The results are discussed with reference to tartaric acid doped poly $(o$-anisidine) synthesized with and without acrylic acid.

\section{Experimental}

The poly $(o$-anisidine $)$ salt was prepared by chemical oxidative polymerization method as described in [10], all chemicals used are of analytical reagent grade. Reaction mixture of $o$-anisidine monomer $(0.1 \mathrm{M}$, Qualigens) in tartaric acid (0.2M, Qualigens) was diluted with water. Then it was chilled to $273-278 \mathrm{~K}$ with constant stirring for $24 \mathrm{~h}$. Then $0.02 \mathrm{M}$ acrylic acid was added to this mixture. The oxidizing agent ammonium per sulphate (Qualigens) was being added dropwise in acidified solution 


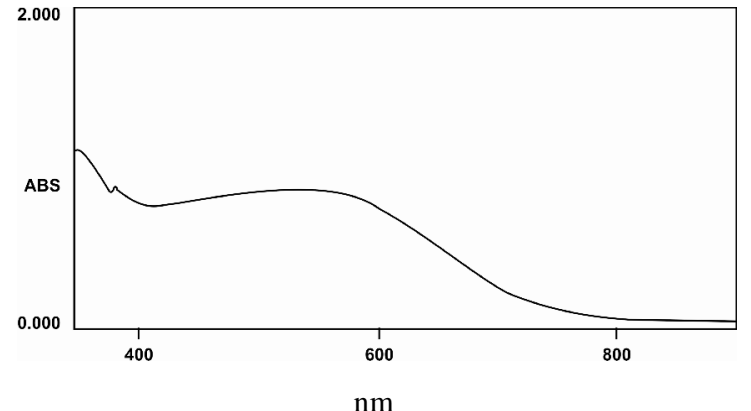

a

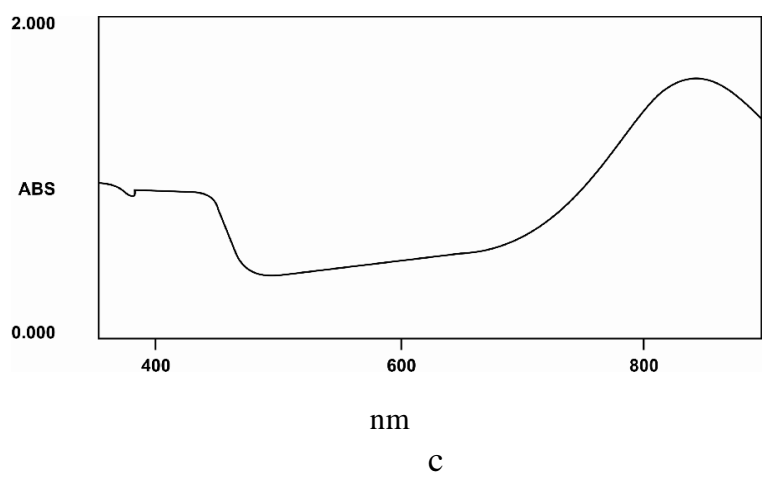

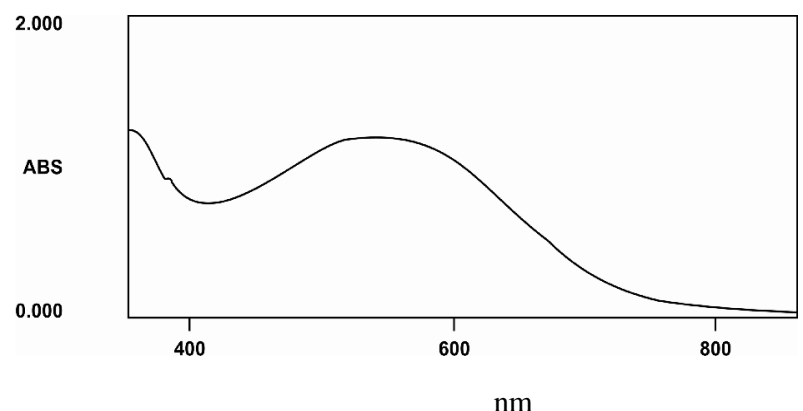

b

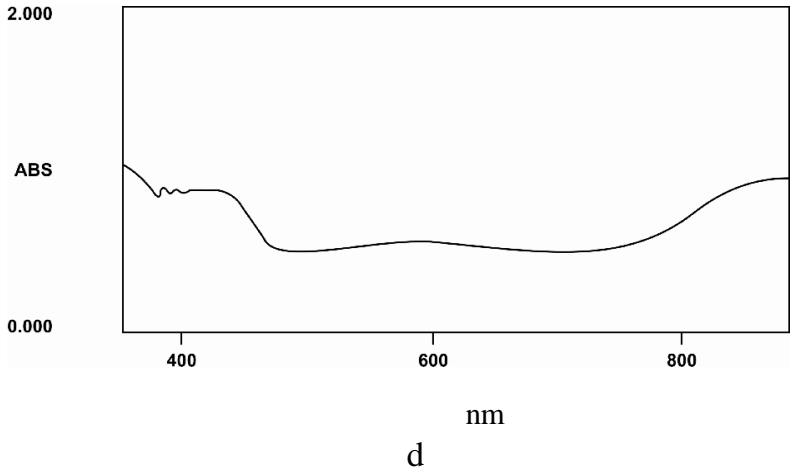

Fig. 1. UV-vis absorption spectra of acrylic acid and tartaric acid doped polymer: tartaric acid doped poly $(o$-anisidine $)$ in NMP (a); acrylic acid doped poly $(o$-anisidine) in NMP (b); tartaric acid doped poly $(o$-anisidine) in $m$-cresol (c) and acrylic acid doped poly $(o$-anisidine) in $m$-cresol (d)

of monomer under constant stirring for $1 \mathrm{~h}$. The violet greenish colored precipitate of polymer was obtained by filtration and washed with water till the filtrate becomes neutral to the litmus. The solid product was dried in a vacuum oven for about $20 \mathrm{~h}$ at $323-333 \mathrm{~K}$.

The UV-vis spectra of polymer dissolve in $m$-cresol were recorded using a Perkin-Elmer Lamda-20 UV-visible spectrophotometer in the range of 300-1000 nm. Infrared spectra of the polymers were recorded using a PerkinElmer 1600A FT-IR spectrophotometer in the range of $4000-400 \mathrm{~cm}^{-1}$. For conductivity measurements the polymer samples were prepared with $1 \mathrm{~cm}$ in diameter and $2 \mathrm{~mm}$ in thickness. These pallets are use to measure the conductivity by two probe method. Sensing measurement was carried out by exposing polymer sample to saturated ammonia solution in a close container.

\section{Results and Discussion}

\subsection{UV-VIS Spectra}

The optical properties of conducting polymers are important to the development and understanding of the basic structures of the material. The conjugation in the polymers implies by their electronic spectra, thus spectroscopy is a powerful tool for characterization of the electronic transitions that occurs in the conducting polymers.
UV-vis spectra of the polymer doped with acrylic acid in the presence of tartaric acid and that doped without tartaric acid was recorded by dissolving these polymers $(5 \% \mathrm{w} / \mathrm{v})$ in $m$-cresol and NMP. The spectral features observed in Fig.1 reveal the enhanced solubility of poly $(o-$ anisidine) polymer synthesized in the presence of acrylic acid. This can be attributed to the presence of greater number of charges on the polymer chain in the acrylic acid doped polymer leading to higher degree of salvation of the polymer due to H-bonding between the solvent and the polymer chains. Consequently, the compact coil structure of the polymer would undergo the transition to an expanded coil or linear structure [11-14].

The optical spectra of the polymers show appreciable changes in $m$-cresol and NMP. In $m$-cresol the polymer exhibits a shoulder peak at $892 \mathrm{~nm}$ with an extended free carrier tail characteristic of an extended coil conformation with increasing absorbance $\sim 800-1100 \mathrm{~nm}$. The sharp intense peak $\sim 597 \mathrm{~nm}$ can be assigned to the localized polarons, which are characteristic of the protonated poly $(o-$ anisidine) together with the extended tail representing the conducting forms of the polymer [12-16].

The intensity of the peak $\sim 597 \mathrm{~nm}$ is greater in acrylic acid doped polymer. This implies that the doping is restored in the $m$-cresol medium apart from the solute - solvent interaction due to its polar nature, which contributes towards the expansion of the coil form of the 


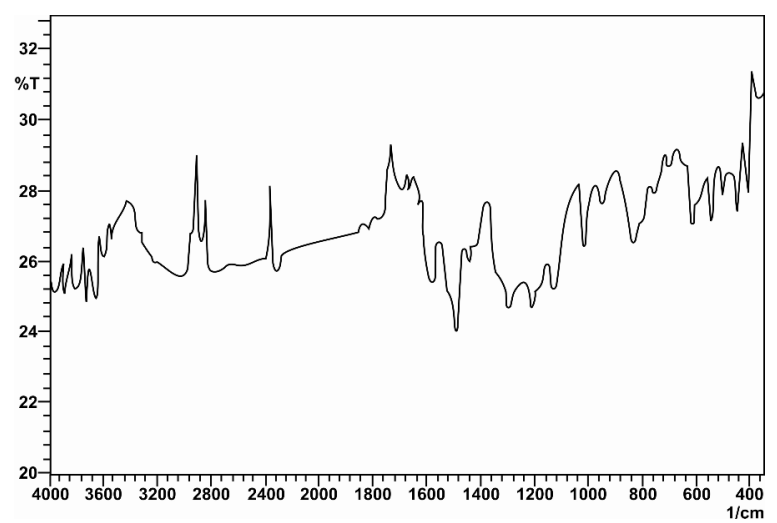

a

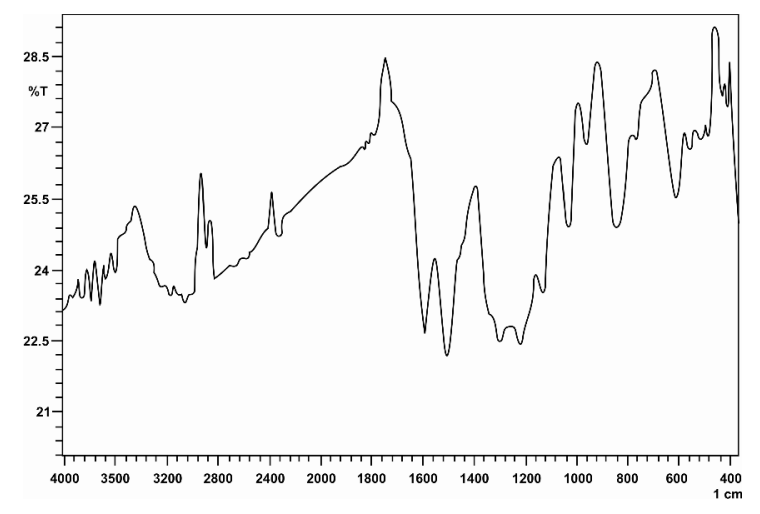

C

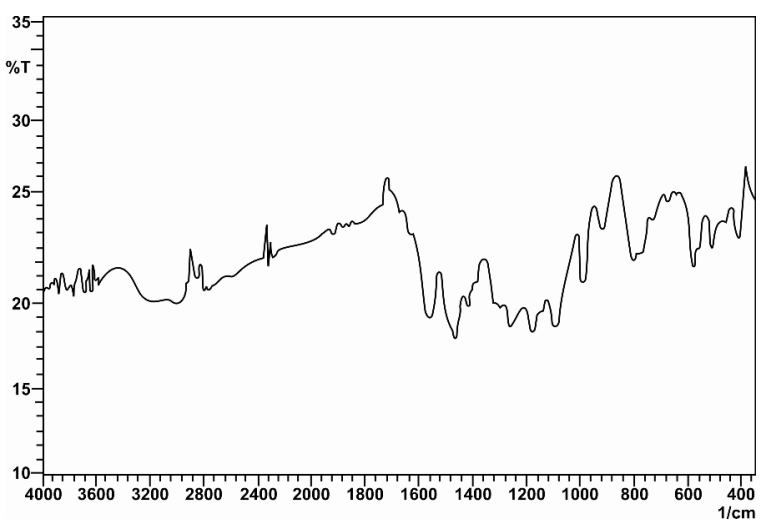

b

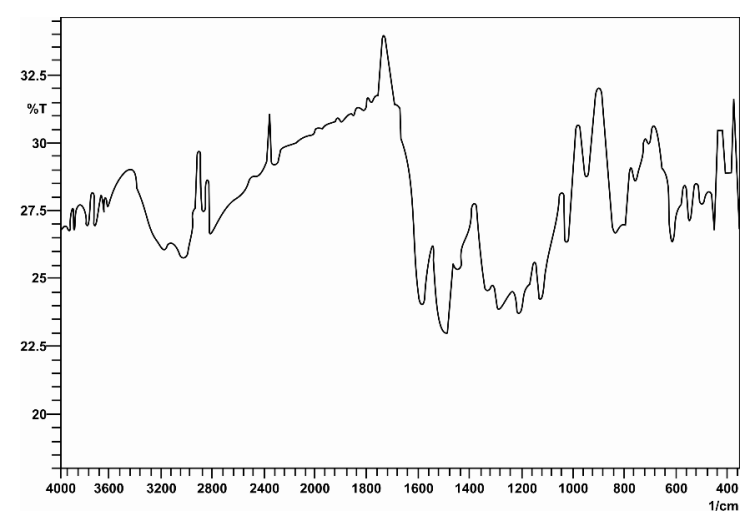

d

Fig. 2. FT-IR spectra of acrylic acid and tartaric acid doped poly (o-anisidine) in $\mathrm{cm}^{-1}$ : tartaric acid doped poly $(o$-anisidine) (a); tartaric acid doped poly $(o$-anisidine $)$ exposed to ammonia (b); acrylic acid doped poly $(o$-anisidine) (c) and acrylic acid doped poly (o-anisidine) exposed to ammonia (d)

polymer and hence the solubility; further extended tail at higher wavelength depicts that $m$-cresol not only serves as a solvent but also acts as an efficient secondary dopant [12-16].

In the presence of NMP as a solvent the extended tail at higher wavelength disappears while a sharp peak is observed at $\sim 551 \mathrm{~nm}$ representing the resulting emeraldine base form of the polymer. As the NMP is a highly polar solvent, solute-solvent interaction would be stronger than in $m$-cresol medium. The carbonyl group present in NMP molecule would try to form $\mathrm{H}$-bond of the $-\mathrm{COOH}$ group of dopant or those present in the $\mathrm{N}$ atom of the polymer chain. This, in turn, would bring about deprotonation of conducting salt phase into insulating emeraldine base form of the polymer in addition to the coiling up of the polymer chain [12-16].

\subsection{FT-IR Spectra}

The infrared spectra of the tartaric acid and acrylic acid doped polymer are given in Fig. 2 and the characteristic peak locations related to the corresponding chemical bonds are listed in Table 1 . However there is a remarkable difference observed in the IR-spectra in terms of specific bands and shifts in the two polymers.
The broad and intense peak at $\sim 3300-3100 \mathrm{~cm}^{-1}$ and $1157 \mathrm{~cm}^{-1}$ in acrylic acid doped polymer accounts for the higher degree of protonation of amine and imine nitrogen but the peaks observed in tartaric acid doped polymer, poly(o-toluidine) is comparatively sharp and narrow, indicating lower degree of protonation and doping. Since both of the polymers exist in conducting polymer, this can be attributed to breaking up of large number of intrachain $\mathrm{H}$-bonds that arise due to the addition of acrylic acid since it acts as a pseudo protonic acid and can coordinate with imine $\mathrm{N}$ atom of the polymer chains, which results in disaggregation of the polymer chains and hence in the extended coil structure and crystallinity [12-18].

The presence of sharp peak at $\sim 2883 \mathrm{~cm}^{-1}$ indicates $\mathrm{C}-\mathrm{H}$ stretching vibration of acrylic acid and $\mathrm{C}-\mathrm{H}$ stretching frequency of $\mathrm{CH}_{3}$ group of $\mathrm{o}$-anisidine, but the peaks obtained from tartaric acid doped polymer is weak and broad. The strong and intense peak at 1580$1590 \mathrm{~cm}^{-1}$ in acrylic acid doped polymer is observed indicating quenoid ring stretching frequency. Along with this peak one more peak is observed at $1492 \mathrm{~cm}^{-1}$, which indicates benzenoid ring stretching vibration. 
FT-IR bands $\left(\mathrm{cm}^{-1}\right)$ for acrylic acid and tartaric acid doped poly(o-anisidine)

\begin{tabular}{|c|c|c|c|l|}
\hline $\begin{array}{c}\text { Poly }(o- \\
\text { anisidine } \\
\text { tartaric acid } \\
\text { doped, } \mathrm{cm}^{-1}\end{array}$ & $\begin{array}{c}\text { Poly }(o \text {-anisidine }) \\
\text { acrylic acid } \\
\text { doped, } \mathrm{cm}^{-1}\end{array}$ & $\begin{array}{c}\text { Poly }(o \text {-anisidine }) \\
\text { acrylic acid doped, } \\
\mathrm{NH}_{3} \text { exposed, } \\
\mathrm{cm}^{-1}\end{array}$ & $\begin{array}{c}\text { Poly }(o \text {-anisidine }) \\
\text { tartaric acid doped, } \\
\mathrm{NH}_{3} \text { exposed, } \mathrm{cm}^{-1}\end{array}$ & \multicolumn{1}{|c|}{ Peak assignment } \\
\hline $707-763$ & 603758 & $617-758$ & 619 & Out of plane C-H bending vibration \\
\hline 835 & 833 & 835 & 837 & Para disubstituted benzene ring \\
\hline 1134 & 1128 & 1128 & 1128 & Vibration band of dopant anion. \\
\hline 1213 & 1215 & 1211 & 1208 & Secondary $(\mathrm{C}-\mathrm{N})$ stretching band \\
\hline 1296 & 1300 & 1290 & 1288 & Aromatic C-N stretching band \\
\hline 1492 & 1435 & 1491 & 1487 & Benzinoid ring stretching band \\
\hline 1573 & 1587 & 1593 & 1589 & Quinoid ring stretching band \\
\hline $1668-1700$ & 1790 & 1700 & - & Carbonyl $(\mathrm{C}=\mathrm{O})$ stretching band \\
\hline 2322 & 2314 & 2360 & 2350 & (NH $)^{+}$saturated amine \\
\hline 2990 & 2821 & 2800 & 2883 & Aliphatic C-H stretching freq. \\
\hline 3040 & 3050 & 3018 & 3040 & C-H aromatic stretching band \\
\hline 3210 & 3280 & 3260 & 3220 & N-H stretching band \\
\hline
\end{tabular}

The benzenoid and quinoide bands are observed at $\sim 1498 \mathrm{~cm}^{-1}$ and $1587 \mathrm{~cm}^{-1}$ which are comparatively broad, weak and shifted to the lower wave number. The spectral intensity of these bands is comparatively typical of highly doped emaraldine salt form of the polymer. The presence of the weak peak at $\sim 1700 \mathrm{~cm}^{-1}$ indicates a non protonated - $\mathrm{COOH}$ group. The broad peak at $1296 \mathrm{~cm}^{-1}$ of tartaric acid and at $1300 \mathrm{~cm}^{-1}$ of acrylic acid doped polymer indicates aromatic $\mathrm{C}-\mathrm{N}$ stretching frequency [12-16].

When the polymer is exposed to ammonia vapor it reveals differences in specific bands which are more significant in acrylic acid doped polymer compared to tartaric acid doped polymer. When the polymer is exposed to ammonia the peak at $3280 \mathrm{~cm}^{-1}$ is shifted to lower frequency at $3260 \mathrm{~cm}^{-1}$, which indicates that the doping level is maintained in the sample even after exposing to ammonia vapors, whereas in tartaric acid doped polymer exposed to ammonia vapor a slight increase in stretching frequency is observed. The peak at $\sim 3260-3220 \mathrm{~cm}^{-1}$ is broadened indicating the oxidation of Nitrogen of the polymer chain. The peak at $\sim 1492 \mathrm{~cm}^{-1}$ is shifted slightly to lower field, i.e. $1434 \mathrm{~cm}^{-1}$ in acrylic acid doped polymer exposed to ammonia vapor indicates the increase in the quinoid form. The peak at $1128 \mathrm{~cm}^{-1}$ and $1134 \mathrm{~cm}^{-1}$ observed indicates that doping is maintained by a free acrylic acid molecule [14-18].

\subsection{Conductivity}

The conductivity of acrylic acid doped $\operatorname{poly}(o$ anisidine) seems to increase upon exposure to ammonia vapors, which can be attributed to the presence of a high concentration of $\mathrm{COO}^{-}$ions serving as dopant along with a few tartaric acid doped sites and trapped $\mathrm{COOH}$ molecules present in polymer matrix. During exposure to ammonia, some molecules of ammonia are adsorbed while others interact with the anions present in the polymer form $\mathrm{NH}_{4}^{+}$anion ${ }^{-}$salt. This leads to a loss of anions together with the charge imbalance caused over the polymer chain. These effects are neutralized by the trap $\mathrm{COOH}$ molecules, which may occupy the free dopant sites thereby increasing the carrier concentration and, hence the conductivity. In the contrast with this, in tartaric acid doped poly $(o-$ anisidine), the conductivity is seen to decrease upon exposure to ammonia vapors. This happens because the ammonia molecules interact with the polymer chains, thereby converting the conducting salts phase of the polymer to insulting emeraldine base form [14-18].

\section{Conclusions}

During in situ synthesis of poly(o-anisidine) in the presence of acrylic acid, the acrylic acid adds to the polymer chains as a dopant. This unique reaction yields a truly soluble conducting emeraldine salt directly without the need for a post-doping process step. This is an easy and scalable one-step method to produce poly ( $o$-anisidine) in its conductive state. In addition to the solubilizing effect, this dopant provides better conductivity. The polymer shows change in resistance under exposure to ammonia vapor, which suggests the applicability of these polymeric materials as ammonia sensors.

\section{Acknowledgements}

One of the authors Dr. Vasant V. Chabukswar is thankful to National Chemical Laboratory, Pune, Indian 
Academy of Sciences (IAS) and Material Research Society of India (MRSI), Bangalore for awarding the summer research fellowship. We thank to Nowrosjee Wadia College, and BCUD, University of Pune, and Indian National Science Association (INSA)India for financial assistance.

\section{References}

[1] Inganas B., Gustafsson G., Gustafsson-Carlberg J. et al.: Nature, 1994, 372, 444.

[2] Genies E. and Lapkowski M.: Synth. Met., 1988, 24, 61.

[3] Chen S. and Fang W.: Macromolecules, 1991, 24, 1242.

[4] Dao Le, Nguyen M. and Paynter R.: Synth. Met., 1991, 4143, 649.

[5] DeArmitt C., Armes P., Winter J. et al.: Polymer, 1993, 34, 158.

[6] Bagheri A., Nateghi M. and Massoumi A.: Synth. Met., $1998,97,85$.

[7] Roy B., Dutta Gupta M., Bhowmik L. and Ray J.: Synth. Met., 1999, 100, 233.

[8] Gabriel A., M. Gustavo, Miras M. and Barbero C.: Synth. Met., 1998, 97, 223.

[9] Moon S. and Park H.: Synth. Met., 1998, 92, 233.

[10] Chen S. and Lee H.: Synth. Met., 1989, 29, E271.

[11] Chen S. and Lee H.:Macromolecule, 1995, 28, 2858.

[12] Santos J., Malmonge J., Conceicao Silva A.: et al.: Synth. Met., 1995, 69, 141.

[13] Anilkumar P. and Jaykannan M.: Langmuir, 2006, 69, 85.

[14] Yoo J. Cross J., Bucholz T. et al.: J. Mater. Chem., 2007, 17, 1268 .

[15] He Y. and Yu H.: Mater. Lett., 2007, 61, 2071.

[16] Li X.and Li Xin.: Mater. Lett., 2007, 61, 2011.

[17] Chabukswar V. and Athawale A.: J. Appl. Polym. Sci., 2001, 79, 1994.
[18] Chabukswar V. and Athawale A.: Chem. \& Chem. Techn., 2008, 2, 257.

[19] He Y. and Yu X.: Mater. Lett., 2007, 61, 2071.

[20] Chabukswar V. and Bhavsar S.: J. Green Chem., accepted 2008.

\section{ХІМІЧНИЙ ОКСИДАЦІЙНИЙ СИНТЕЗ I ХАРАКТЕРИСТИКА РОЗЧИННОГО ПРОВІДНОГО ПОЛІ(О-АНІЗИДИНУ), МОДИФІКОВАНОГО ОРГАНІЧНОЮ КИСЛОТОЮ}

Анотація. Методом хімічної оксидаційної полімеризації синтезовано полі(о-анізидин) з додаванням та без акрилової кислоти. Запропонований метод розроблений для безпосереднього синтезу емеральдинової солі полі(о-анізидину), розчиненої у загальновідомих органічних розчинниках, зокрема в м-крезолі, $N$-метилпіролідоні, диметилсульфоксиді та ін., без необхідності перетворення солевої фази в основну форму. Модифікований акриловою кислотою полімер приготовлений з використанням винної кислоти іє більи розчинним у м-крезолі i N-метилпіролідонi, порівняно з полі(о-анізидином), синтезованим у відсутності акрилової кислоти. Структура полімеру підтверджена УФ-спектроскопією. Вплив розчинника на властивості полімеру підтверджені Фур'єспектроскопічними дослідженнями. Встановлено, щзо провідність полі(о-анізидину), модифікованого акриловою кислотою, є вищуою порівняно з полімером, щзо не містить фрагменти кислоти. Показана залежність стійкості полімеру, модифікованого винною кислотою і приготовленого в середовищі акрилової кислоти, до дї̈ парів амонію.

Ключові слова: полі(о-анізидин), розчинність, провідність, акрилова кислота. 